\title{
Brethren Behaving Badly: A Deviant Approach to Medieval Antifraternalism
}

\author{
By G. Geltner
}

Clizia, the titular protagonist of Machiavelli's play, was trapped between her master's sexual advances and her mistress's attempt to avoid scandal. For their part, and with no arbiter in sight, husband and wife remained at strategic loggerheads as to whom the young girl should marry. After lengthy bickering, a solution finally emerged:

SOFronia: Who should we turn to?

Nicomaco: Who else but to our own confessor fra Timoteo, who is a little saint and has already performed several miracles.

SOFRONIA: Such as?

Nicomaco: What do you mean, "Such as?" Don't you know that through his prayers donna Lucrezia, messer Nicia Calfucci's sterile wife, became pregnant?

SOFRONIA: What a miracle, a friar gets a woman pregnant! It would have been a real miracle if a nun got her pregnant!

$(\text { Clizia } 2.3)^{1}$

That medieval and later friars were the butt of numerous jokes, common objects of satire, and even victims of violence continues to perpetuate their image in popular culture and modern scholarship as unwanted parasites, even devils. ${ }^{2}$ However, and as literary, religious, and social historians have certainly become aware, prior to the sixteenth century the vast majority of the mendicants' critics were driven by a desire for the friars' reform, not by a radical quest for their abolition. ${ }^{3}$ Only

Nascent versions of this paper were delivered in seminars at Oxford University, the Institute of Historical Research (London), and the Program in Medieval Studies (Princeton). I wish to thank the seminars' conveners-Ian Forrest and John Blair, Trevor Dean and Kate Lowe, and D. Vance Smith—for their invitation and hospitality, and the participants for their discussion. I am also grateful to Stephen Mossman, William Chester Jordan, Jeff Schwegman, and the anonymous reviewers for this journal for helping me rethink and refine earlier drafts. Jens Röhrkasten and Stephen Mossman kindly shared their copies of some archival documents. Research funding was generously provided by Yad Hanadiv Foundation (Jerusalem) and the Zilkha Trust (Lincoln College, Oxford).

${ }^{1}$ Guido Mazzoni and Mario Casella, eds., Tutte le opere di Niccolò Machiavelli (Florence, 1929), p. 670 .

${ }^{2}$ Joseph Spencer Kennard, The Friar in Fiction, Sincerity in Art, and Other Essays (New York, 1923); G. G. Coulton, Five Centuries of Religion, 2: The Friars and the Dead Weight of Tradition, 1200-1400 A.D. (Cambridge, Eng., 1927), pp. 179-94; Penn R. Szittya, The Antifraternal Tradition in Medieval Literature (Princeton, N.J., 1986).

${ }^{3}$ Revisions by literary historians are discussed in the following paragraph and $\mathrm{nn} .8-13$. Religious and social historians, from Augustine Thompson, Cities of God: The Religion of the Italian Communes, 1125-1325 (University Park, Pa., 2005), pp. 419-56; to Robert Swanson, Religion and Devotion in Europe, c. 1215-c. 1515 (Cambridge, Eng., 1995), pp. 249-52; to Geoffrey Dipple, Antifraternalism and Anticlericalism in the German Reformation: Johann Eberlin von Günzburg and the Campaign against the

Speculum 85 (2010) doi:10.1017/S0038713409990947 
a handful of thirteenth- and fourteenth-century clerics called for the elimination of the mendicant orders from the hierarchy of the church on ecclesiological grounds: men such as William of Saint-Amour, Richard FitzRalph, John Wyclif, Johannes Malkaw, and Konrad Waldhauser do not just head this list-they constitute it almost in full. Most of their contemporary partisans-Gerard of Abbeville, Henry of Ghent, John of Pouilly, Jean d'Anneux-disputed specific privileges granted to the friars, not the orders' right to exist. ${ }^{4}$ Moreover, the modern fame of these polemicists stems substantially from humanist and post-Reformation anticlericalism, early nationalist propaganda, and various strands of liberal and secularist thought, all of which are products of later eras, quite remote from the diverse contexts of the original debates. ${ }^{5}$ With the possible-and only so-exception of Wyclif, those few men who called to eradicate the mendicant orders were conservative or indeed reactionary clerics, not budding atheists or progressive revolutionaries. ${ }^{6}$ Yet these authors' identity is often overlooked by modern scholars who unnecessarily or simply unknowingly collapse antifraternalism into anticlericalism. ${ }^{7}$

As for thirteenth- and fourteenth-century authors who constitute the so-called gallery of antifraternal writers-Jean de Meun, Rutebeuf, Boccaccio, Chaucer, and Langland, to name the usual suspects- their partisanship has been increasingly thrown into doubt. ${ }^{8}$ More than a generation ago, Jean Batamy and Jill Mann independently underscored the enormous debt of antifraternal literature to the long-standing conventions of estate satire - the former arguing that friars are often undistinguishable from monks or clergymen in generic protests against corruption, ${ }^{9}$ the latter asserting that " $[\mathrm{f}] \mathrm{ar}$

Friars (Aldershot, Eng., 1996), pp. 1-36, have been more directly stimulated by the revisionist (though differing) approaches of Christopher Haigh, “Anticlericalism in the English Reformation," History 68 (1983), 391-407; and Eamon Duffy, The Stripping of the Altars: Traditional Religion in England, c. 1400-c. 1580, 2nd ed. (New Haven, Conn., 2005). John Van Engen, "Late Medieval Anticlericalism: The Case of the New Devout," in Anticlericalism in Late Medieval and Early Modern Europe, ed. Peter A. Dykema and Heiko A. Oberman, Studies in Medieval and Reformation Thought 51 (Leiden, 1993), pp. 19-52, summarized the impetus of such investigations in asking, "[W] as true anticlericalism even thinkable in the Middle Ages?" (p. 20).

${ }^{4}$ See G. Geltner, William of Saint-Amour's "De periculis novissimorum temporum": An Introduction, Edition, and Translation, Dallas Medieval Texts and Translations 8 (Leuven, 2007), pp. 18-22.

${ }^{5}$ For instance, Mary Morton Wood, The Spirit of Protest in Old French Literature (New York, 1917), p. 133, asserts that Rutebeuf's defense of William of Saint-Amour "furnishe[s] the best refutation of the current opinion that until the time of Luther men submitted to ecclesiastical tyranny"; "the scholars and poets who stood around Guillaume were men who dared to think for themselves, unhampered by slavish adherence to time-honored institutions."

${ }^{6}$ For a mitigated view of Wyclif's revolutionary zeal as regards the mendicant orders see Margaret Aston, “Caim's Castles': Poverty, Politics, and Disendowment," in The Church, Politics and Patronage in the Fifteenth Century, ed. Barrie Dobson (Gloucester, Eng., 1984), pp. 45-81.

${ }^{7}$ Famously, Johan Huizinga, The Waning of the Middle Ages, trans. F. Hopman (Garden City, N.Y., 1954), pp. 178-80. And see Patricia Anne Odber de Baubeta, Anticlerical Satire in Medieval Portuguese Literature (Lewiston, N.Y., 1992); Dykema and Oberman, eds., Anticlericalism, passim; and L'anticlericalisme en France méridionale (fin XIIe-début XIVe siècle), Cahiers de Fanjeaux 38 (Toulouse, 2003).

${ }^{8}$ Tiberius Denkinger, Die Bettelorden in der französischen didaktischen Literatur des Mittelalters (Münster, 1915); Wendy Scase, "Piers Plowman" and the New Anticlericalism, Cambridge Studies in Medieval Literature 4 (Cambridge, Eng., 1989); and above, n. 2.

"Jean Batamy, "L'image des franciscaines dans les 'revues d'États' du XIIIe au XVIe siècle," in Mouvements franciscains et société française, XIIe-XXe siècles, ed. André Vauchez, Beauchesne Religions 14 (Paris, 1984), pp. 61-74. 
from drawing new inspiration from real life, Chaucer seems to have been most stimulated by the possibility of exploiting a rich literary tradition" in his treatment of monks and friars. ${ }^{10}$ More recently, Kathryn Kerby-Fulton and, later, Lawrence Clopper turned a dominant interpretation of Piers Plowman virtually on its head by demonstrating that Langland's sincere concerns about religious mendicancy, especially regarding the Franciscan order, reflect the friars' departure from their founders' ideals rather than a wish to see them eradicated. ${ }^{11}$ My own study of friar figures in works by Jean de Meun and Geoffrey Chaucer suggests that these are more complex fabrications than is commonly recognized; insofar as they engage or broadcast a specific social critique, it is hypocrisy, not partisan antifraternalism. ${ }^{12}$

Thus, what Penn Szittya and others have dubbed "the medieval antifraternal tradition" shares much common ground with numerous homegrown critics, from Joachimite Franciscans and their Spiritual followers to undisputedly orthodox disciplinarians such as Bonaventure and Humbert of Romans-all of whom decried the friars' fallenness in unambiguous terms and for the stated purpose of their improvement, not elimination. ${ }^{13}$ (Fiery intramendicant quarrels share a similar premise, of course. $)^{14}$ All this is not to deny that throughout their early phase the mendicant orders faced allegations of ecclesiastical incongruity, or that literary fiction played an important role in forging an antifraternal tradition, but rather to suggest that we may be misconstruing or unnecessarily limiting medieval antifraternalism in treating it as an exclusively doctrinal or literary issue; antifraternal resentment could equally have been a reformist response to the brethren's misbehavior from a normative point of view.

${ }^{10}$ Jill Mann, Chaucer and Medieval Estates Satire: The Literature of Social Classes and the General Prologue to the Canterbury Tales (Cambridge, Eng., 1973), p. 17; adding (p. 39), "As with the Monk, Chaucer seems to have more ends in view than moral criticism of the character he is describing." And see Arnold Williams, "Chaucer and the Friars," Speculum 28 (1953), 499-513; John V. Fleming, "The Antifraternalism of the Summoner's Tale," Journal of English and Germanic Philology 65 (1966), 688-700; Nicholas Havely, "Chaucer, Boccaccio, and the Friars," in Chaucer and the Italian Trecento, ed. Piero Boitani (Cambridge, Eng., 1983), pp. 249-68; and idem, "Chaucer's Friar and Merchant," Chancer Review 13 (1978-89), 337-45. However, as Odber de Baubeta, Anticlerical Satire, p. 40, justly remarks, "[T]he fact that the satirist inveighs against clerical abuse in platitudes or commonplaces need not necessarily detract from the sincerity of his convictions."

${ }^{11}$ Kathryn Kerby-Fulton, Reformist Apocalypticism and "Piers Plowman," Cambridge Studies in Medieval Literature 7 (Cambridge, Eng., 1990), pp. 133-61; Lawrence M. Clopper, "Songes of Rechelesnesse": Langland and the Franciscans (Ann Arbor, Mich., 1997).

${ }^{12}$ G. Geltner, "Faux Semblants: Antifraternalism Reconsidered in Jean de Meun and Chaucer," Studies in Philology 101 (2004), 357-80.

${ }^{13}$ See G. Geltner, “A False Start to Medieval Antifraternalism: William of St. Amour's De periculis novissimorum temporum," in Defenders and Critics of Franciscan Life, ed. Michael F. Cusato and G. Geltner, The Medieval Franciscans 6 (Leiden, 2009), pp. 127-43.

${ }^{14}$ Benedikt Maria Reichert, ed., Chronica et chronicorum excerpta historiam Ordinis Praedicatorum illustrantia, Monumenta Ordinis Fratrum Praedicatorum Historica 7/1 (Rome, 1904), p. 24; R. W. Emery, "The Second Council of Lyons and the Mendicant Orders," Catholic Historical Review 39 (1953), 257-71; J. P. H. Clark, "A Defence of the Carmelite Order by John Hornby, O. Carm., A.D. 1374," Carmelus 32 (1985), 73-106; Frances Andrews, The Other Friars: The Carmelite, Augustinian, Sack and Pied Friars in the Middle Ages (Woodbridge, Eng., 2006), pp. 18-19; Holly J. Grieco, "Franciscan Inquisition and Mendicant Rivalry in Mid-Thirteenth-Century Marseille," Journal of Medieval History 34 (2008), 275-90. 
But if antifraternalism, even in its more prevalent, reform-driven variety, reflects genuine concern, to what extent is it based on the friars' actual or perceived misbehavior? In other words, can we ascertain that allegations of corruption among mendicants reach beyond satirical tropes or the rhetoric of fallenness? So far social and religious historians have been wont to take medieval poets, polemicists, and reformers at their word. ${ }^{15}$ By doing so they allowed the careful evaluation of the friars' behavior and its broad perception by contemporaries to fall by the wayside, even though many alternative (and compared with poetry, less ambiguous) sources are available to that end. In particular, three types of records afford a more nuanced view of mendicant discipline both in and out of the convent: internal administrative correspondence, the acta of the orders' general and provincial chapters, and external documents of practice such as wills and court records. The present study focuses on these types of sources, for, although they are not obscure nor can they claim exclusivity when it comes to illuminating the social history of the mendicants, their relative neglect in this context requires redress. ${ }^{16}$

It goes almost without saying that highlighting the mendicants' deviance is not an indictment of the orders themselves. ${ }^{17}$ Friars' misconduct, as the Dominican scholar Tommaso Masetti acknowledged long ago, is part and parcel of their history, although, unlike modern sociologists, he attributed delinquency to innate human corruption, not to social maintenance. ${ }^{18}$ But whatever its "origins," official deviance is simpler to define and identify among medieval friars (and monks) than it

\footnotetext{
${ }^{15}$ Thus David Knowles, The Religious Orders in England, 3 vols. (Cambridge, Eng., 1961-62), 2:114, asserts that "it is hard to escape the conviction" that Langland, Wyclif, and Chaucer "are in their different ways witnesses to a corruption among the mendicants ... which was only too real." Gerald Harriss, Shaping the Nation: England, 1360-1461 (Oxford, 2006), p. 332, likewise remarks that the friars' "proselytizing and poverty made them butts for anticlerical satire and denunciations, exemplified in Langland and Chaucer and in the vitriolic attacks of Wyclif and the Lollards." And in a chapter entitled "Boccaccio, Satire and the Friars," Michael Robson, The Franciscans in the Middle Ages (Woodbridge, Eng., 2006), p. 157, allows that "Boccaccio's raconteurs speak of the friars in a way that is plausible and credible. Their image of the friar is in tune with the pleas of the internal reformers and the complaints of critics." While many authors took part in shaping antifraternal traditions, such statements run dangerously close to placing literary satire, doctrinal polemics, and the rhetoric of spiritual reform on a par as historical documents that communicate a similar and equally unmitigated reality.

${ }^{16}$ Mendicant documents of practice are a main concern of the orders' numerous students, above all in their dedicated journals; and civic court records have long been a staple for social, political, and legal historians. However, with the partial exception of Jens Röhrkasten, The Mendicant Houses of Medieval London, 1221-1539, Vita Regularis, Abhandlungen, 21 (Münster, 2004), pp. 167-74, no one has used this conjunction of sources specifically to explore mendicant discipline transregionally and over a long period.

${ }^{17}$ Even if it contrasts with the idealized accounts of Galvano Fiamma, Cronica Ordinis Praedicatorum ab anno 1170 usque ad 1333, ed. Benedikt Maria Reichert, Monumenta Ordinis Fratrum Praedicatorum Historica 2/1 (Rome, 1897), pp. 39-51; and Pietro Lippini, La vita quotidiana di un convento medievale: Gli ambienti, le regole, l'orario e le mansioni dei frati domenicani del trecesimo secolo, Collana Attendite ad Petram 5 (Bologna, 1990), pp. 351-59.

${ }^{18}$ Pio Tommaso Masetti, Monumenta et antiquitates veteris disciplinae Ordinis Praedicatorum ab anno 1216 ad 1348, 2 vols. (Rome, 1864), 1:162: "Nec putare debemus temporibus de quibus disserimus, improbos defuisse, qui propriae immemores conditionis intra vel extra Claustra Praelatis haud modicas inferebant molestias; id nos inficiari nec volumus, nec possumus, quin etiam pluribus in locis ingenue confessi sumus. Sed quoadusque homines erimus corruptae naturae miserias ferre cogimur, quas reprimere quidem ac coercere, extinguere vero non possumus." A fine survey of the pertinent sociological
} 
would be among most other contemporaries. After all, if there is any premodern candidate for the title of a "total" institution, it would be the monastery, for it, like the modern asylum, is "a place of residence and work where a large number of like-situated individuals, cut off from the wider society for an appreciable period of time, together lead an enclosed, formally administered round of life."19 True, friars were not as spatially confined as most monks; indeed, they were often accused of being gyrovagi, or wanderers, famously detested by St. Benedict. ${ }^{20}$ But they did lead common, theoretically egalitarian, and highly regulated lives according to a written rule that was enforced by their superiors. Moreover, however ambiguous as a term, obedience was central to the friars' spirituality, and punishments meted out for undermining it were common and potentially harsh. ${ }^{21}$ Whatever the peculiarities of mendicant life, normative borders were as explicit and well demarcated among medieval friars as within any monastic order, affording the social historian and the historical sociologist a useful site for studying the construction of deviancy.

Despite the relatively clear divide between friars' licit and illicit conducts, there has been no attempt systematically to examine the frequency and character of indiscipline among them or to assess the effect of misbehavior upon the orders' self- and public image. The first section of this study offers a corrective by marshaling data on mendicants' major infractions, especially among the members of the Order of Preachers (also known as Dominicans, Friars Preachers, Black Friars, or Jacobins). The relative gravity of an infraction has been determined on the basis of the act's description in the sources (usually some form of violence, sexual misconduct, or gross insubordination) and in view of the reprimand that followed. By and large, major offenses were those punishable by incarceration, relocation, or banishment, rather than by lighter penances such as fasts, masses, or flagellations. The focus on the followers of St. Dominic is due to the fact that the order's pertinent documentation is superior to that of any other major order, including the Franciscans, both in

theory is David Downes and Paul Rock, Understanding Deviance: A Guide to the Sociology of Crime and Rule-Breaking, 5th ed. (Oxford, 2007).

${ }^{19}$ Erving Goffman, Asylums: Essays on the Social Situation of Mental Patients and Other Inmates (Garden City, N.Y., 1961), p. xiii-commonly regarded as the seminal definition of the term "total institution." And see Michel Foucault, Surveiller et punir: Naissance de la prison (Paris, 1975); and Samuel E. Wallace, ed., Total Institutions, Transaction Books, TA 20 (Chicago, 1971). Sarah Foot, Monastic Life in Anglo-Saxon England, c. 600-900 (Cambridge, Eng., 2006), pp. 38-42, discusses and qualifies the appellation. A fuller exploration is Richard Sowerby, "Punishment and the Transformation of Space in Anglo-Saxon Monasteries” (M.Litt. thesis, University of St. Andrews, 2008).

${ }^{20}$ Ramona Sickert, "Extra obedientiam evagari . . . : Zur zeitgenössischen Deutung der Mobilität von Franziskanern und Dominikanern im 13. Jahrhundert," in Oboedientia: Zu Formen und Grenzen von Macht und Unterordnung im mittelalterlichen Religiosentum, ed. Sébastien Barret and Gert Melville, Vita Regularis, Abhandlungen, 27 (Münster, 2005), pp. 159-80; and eadem, Wenn Klosterbrüder zu Jahrmarktsbrüdern werden: Studien zur Wabrnehmung der Franziskaner und Dominikaner im 13. Jahrhundert, Vita Regularis, Abhandlungen, 28 (Berlin, 2006), pp. 191-99.

${ }^{21}$ Barret and Melville, eds., Oboedientia, is a recent reexamination of the term in the monastic context, exposing the variety of its meanings and, indeed, historical constructions. I was unable to consult Thomas Füser, Mönche im Konflikt: Zum Spannungsfeld von Norm, Devianz und Sanktion bei den Cisterziensern und Cluniazensern (12. bis frühes 14. Jahrbundert), Vita Regularis, Abhandlungen, 9 (Münster, 2000), in time for this publication. 
quantity and in precision. ${ }^{22}$ As the doyen of Franciscan studies A. G. Little once admitted, not without a touch of envy, "If you want to know what happened, the Dominicans will be the safest guides: if you want to know how it struck a contemporary ... , consult the Franciscans." 23

Little's distinction between reality and perception is crucial, for the available information cannot be evaluated in statistical terms alone. Deviant friars in any city or region were, by definition, few and far between. ${ }^{24}$ Yet, as the second section of this study demonstrates, the mendicants' high public profile amplified what otherwise might have been glossed over as isolated events and exposed the brethren (as they were well aware) to allegations of scandalous behavior. Most important, the friars' general disrepute, whether truthful or exaggerated, spread through different channels and could be manipulated to different ends: tensions between the church and urban regimes, the envy of clergymen and monks, local property disputes-all played a role. But whatever the catalyst of infamy, it is deviancy itself, in conjunction with a reactionary ecclesiology and the brethren's high public profile, that supplies a more satisfying context for the early development of antifraternal sentiments, broadly defined. ${ }^{25}$

\section{Dominican Deviance: A Case Study}

In nearly twenty years as master general of the Dominican order, Raymond of Capua (1330-99) dealt directly with numerous infractions perpetrated by his underlings. On what must have been a particularly demoralizing day, 18 March 1387, he addressed several disturbing incidents discovered among the Italian brethren. First, he asked Antonio, prior of Urbino, to look into allegations made against a certain fra Marino "regarding a crime committed by him in the city of Camerino (super crimine commisso per eum in civitate Camerinensi)." Should Marino confess his misdeed, which remains typically obscure, he is to be incarcerated for six months at the order's prison in Faenza. Next, Raymond instructed Caterina, prioress of St. Archangel in Fermo, to imprison Sister Vagnola, "on account of the many crimes committed by her (propter crimina plurima per ipsam commissa)," specifying that, while incarcerated, she is to fast three days a week on bread and water. An accomplice of Vagnola's,

\footnotetext{
${ }^{22}$ Franz Ehrle, "Die ältesten Redactionen der Generalconstitutionen des Franziskanerordens," Archiv für Literatur- und Kirchengeschichte des Mittelalters 6 (1892), 1-138. A unique exception is Luzern, Zentralbibliothek, MS BB.129.4을 a Franciscan formulary excerpted in Clément Schmitt, "Documents sur la province franciscaine de Strasbourg aux XIV-XVe siècles d'après un formulaire de Lucerne," Archivum Franciscanum historicum 59 (1966), 209-300, esp. pp. 216-17 and no. 15 (p. 235), which attest several major violations among local Minorites.

${ }^{23}$ A. G. Little, "Chronicles of the Mendicant Friars," in Franciscan Papers, Lists, and Documents, Publications of the University of Manchester 284; Publications of the University of Manchester, Historical Series, 81 (Manchester, Eng., 1943), p. 41.

${ }^{24}$ For a neo-Durkheimian approach to deviance see Kai T. Erikson, Wayward Puritans: A Study in the Sociology of Deviance (New York, 1966).

${ }^{25}$ A similar emphasis on deviant behavior over a religious worldview is laid, albeit in a different polemical context, by Israel Jacob Yuval, Two Nations in Your Womb: Perceptions of Jews and Christians in Late Antiquity and the Middle Ages, trans. Barbara Harshav and Jonathan Chipman (Berkeley, Calif., 2006), pp. 135-204.
} 
Brother Venanzio of Camerino, was likewise to be imprisoned by the prior of Rimini "on account of the crime committed [by him] with the said Sister Vagnola (propter crimen commissum cum sorore Vagnola supradicta)." The day's work was not done, however, until Raymond dispatched yet another letter, this time to Ugo of Ravenna, prior of the Ancona convent, ordering him to incarcerate Brother Ugolino of Pesaro and examine him "regarding intolerable excesses repeatedly committed by him in the convents of Pesaro, Recanati, and others, and especially concerning what he did on a public way to the prior of Faenza (de intolerabilibus excessibus multoties per ipsum commissis in conventu Pesauriensi et Racanatensi et aliis, et maxime super quae fecit in strata publica priori Fanensi)." 26

Raymond's extant correspondence suggests that, although 18 March 1387 may have been an unusually taxing day, the offenses themselves were typical both among and beyond the order's Italian convents and throughout its rank and file: the prior of Rimini was charged in 1389 with assaulting two of the brethren and destroying the convent's vineyards; Guillaume, a lay brother, was expelled from the convent at Bruges in 1390 for what appears to be theft; large-scale disobedience and scandala were detected at the Viterbo convent in 1390; in early 1398 Sister Ursula of Sechdorf (Eschdorf?) left her convent along with nine other sisters, all of whom refused to return until their joint sentence of excommunication was lifted; later that year, Brother Ivo of Gladbach impregnated an anonymous sister at the convent of St. Gertrude of Cologne while serving as her confessor; and so it goes. ${ }^{27}$ On average, the Dominican master general intervened in two or more major incidents a year, from internal uprisings to sexual promiscuity to theft and violence.

With one exception to be discussed below, Raymond's register is the only extant Dominican collection of its kind prior to 1400, the cutoff date of the present study. Even assuming that the surviving dossier is complete, however, it probably relates a fraction of the friars' major violations in that period. The Dominican constitutions delegated disciplinary responsibilities down the order's hierarchy, from the master general through the provincial diffinitores and priors to the priors and subpriors of individual houses. In theory, then, few cases should have required Raymond's direct intervention. ${ }^{28}$ Furthermore, even within the context of a general chapter, most disciplinary actions were discussed and concluded by tribunals appointed for that purpose, and without the master general's ruling. ${ }^{29}$ From the standpoint of deviancy, therefore, Raymond's writings reveal the tip of an iceberg, notwithstanding his particular commitment to the order's moral reform.

\footnotetext{
${ }^{26}$ Registrum litterarum Fr. Raymundi de Vineis Capuani, Magistri Ordinis, 1380-1399, ed. Thomas Kaeppeli, Monumenta Ordinis Fratrum Praedicatorum Historica 19 (Rome, 1937), "Provincia Lombardiae inferioris" 30-33, p. 10.

${ }^{27}$ Ibid., "Provincia Lombardiae inferioris" 147, p. 23; "Provincia Franciae" 9, p. 2; "Provincia Romana" 367-69, p. 99; "Provincia Teutoniae" 249-50, p. 150, and 279, p. 154.

${ }^{28}$ Humbert of Romans, "Instructiones de officiis ordinis" 1.4, in Opera de vita regulari, ed. Joachim Joseph Berthier, 2 vols. (Rome, 1888-89), 2:184-85.

${ }^{29}$ G. R. Galbraith, The Constitution of the Dominican Order, 1216 to 1360, Publications of the University of Manchester 170; Publications of the University of Manchester, Historical Series, 44 (Manchester, Eng., 1925), pp. 83-84; William A. Hinnebusch, The History of the Dominican Order, 2 vols. (New York, 196673), 1:169-250.
} 
One rung lower on the order's administrative ladder, the annual general assemblies generated a more detailed picture of the brethren's infractions, but it, too, is far from complete. Although a nearly unbroken record of such acta or redacted protocols survives from 1220 onward, their texts seldom describe violations in detail, preferring instead the use of opaque terms such as scandalum, crimen, excessus, irreverentia, and so forth. Moreover, and as already mentioned, most infractions were handled by special tribunals or committees, a précis of whose decisions was brought before the general assembly and approved en bloc. ${ }^{30}$ Nor are these committees' specific procedures anywhere clarified. ${ }^{31}$ In light of the great variety of offenses that were discussed at the general chapters, from minor disobediences to grave crimes, there seem to have been no rigid criteria to differentiate between incidents that found their way into the official minutes and those omitted from them.

Nonetheless, the proceedings' iniunctiones penitenciarum or clauses de penitenciis, which appear almost continuously from 1240 onward, add precious information on misbehavior and its repercussions among early Dominicans. Virtually all such sections deal with minor disobediences, such as failing to reach the chapter on time or doing so uninvited, acting insolently to a superior, preaching outside a convent's allocated area, accepting illicit gifts, and pawning the convent's possessions without permission. The punishments themselves are usually a combination of traditional penances: fasts, prayers, masses, and flagellations. Occasionally, however, the offense is deemed graver and the judges' (or the assembly's) response is harsher, ranging from the cancellation of certain privileges, a status, or an office to a fixed-term banishment or permanent relocation to temporary or perpetual incarceration. Following an ancient monastic tradition, the ultimate penalty for serious and repeat infractions was expulsion from the order. ${ }^{32}$

A survey of penitential clauses promulgated by the general chapters for the period 1240-1400 reveals dozens of severe violations, involving scores of friars throughout the order's provinces. In 1267, for instance, the priors of Stralsund and Greifswald, near the Baltic shore, were removed from their offices "on account of the scandals perpetrated by them and by their brethren in the city of Greifswald" in the course of a dispute over begging rights. In addition, they were both given a string of penances, though only the prior of Greifswald was to leave his convent, never to return unless by a special dispensation. Johannes of Bremen, a third friar implicated in the affair, suffered long penances and was permanently removed "from his convent and land (et removemus eum de conventu et terra sua)." 33 In 1301 more than twenty

\footnotetext{
${ }^{30}$ Hinnebusch, History, 1:182. On the general chapters' sequence see Simon Tugwell, "The Evolution of Dominican Structures of Government, II: The First Dominican Provinces," Archivum Fratrum Praedicatorum 70 (2000), 100-109.

${ }^{31}$ Simon Tugwell, "The Evolution of Dominican Structures of Government, III: The Early Development of the Second Distinction of the Constitutions," Archivum Fratrum Praedicatorum 71 (2001), 110; Acta capitulorum provincialium Ordinis Fratrum Praedicatorum ... (1239-1302), ed. C. Douais, 2 vols. (Toulouse, 1894-95), 1:xliii-xliv.

${ }^{32}$ Humbert of Romans, "Instructiones" 2.6, 2:198.

${ }^{33}$ Acta capitulorum generalium Ordinis Praedicatorum, ed. Benedikt Maria Reichert, Monumenta Ordininis Fratrum Praedicatorum Historica 3, 4, and 8-14 (Rome, 1898-1904), 1:139-40: “Absolvimus priores Sundensem de provincia Theutonie et Gripsvaldensem de provincia Polonie propter scandala facta ab ipsis et fratribus eorum in civitate Gripsvaldensi coram religiosis publice occasione questus;
} 
Rhineland friars were involved in a series of unspecified scandala, for which many of them were relocated, stripped of their sometimes high offices, deprived of their privileges of preaching and confession, and barred from reelection to any office for different durations. ${ }^{34}$ In 1321 two friars from the convent of Strasbourg "beat their provincial prior, threw him to the ground, seized and violently incarcerated him; and they wished to kill him, and injured both his socius and his servant." The assailants were sentenced to perpetual incarceration on bread and water. ${ }^{35}$ Simon, the prior of Rouen, was removed from his office and exiled in 1342 for his negligence, "on account of which ... disorders and quarrels abounded in that convent, in both spiritual and material affairs." 36 At the same meeting, another French friar, Guillaume Calatot, was convicted of forging letters of his provincial prior. He was sent "misericorditer" to prison and lost all his privileges. ${ }^{37}$ As with the evidence drawn from Raymond of Capua's register, a list limited to major infractions alone would fill many more pages, notwithstanding the paucity of information contained in the sources.

Before surveying the evidence for the friars' disciplinary infractions as reflected in the acta of their provincial chapters, it is worth pausing to examine a unique document related to the order's administration. It is a register containing some 150 letters, mostly written by the German provincial Hermann von Minden (1286-90). The dossier's discovery in a Berlin manuscript more than a century ago was instrumental for the study of a specific event in the history of the Dominicans in Alsace, namely, the strife between the brethren and the Strasbourg magistrates from the mid to the late 1280s — an incident that culminated with the friars' temporary ejection from the city, an ensuing interdict, and the gradual spread of tensions to adjacent towns. ${ }^{38}$ For my purposes, however, the collection illuminates the order's routine disciplinary activities at the provincial level.

Hermann addressed a number of major infractions, some of which were closely linked to the regional tensions. In early 1289 , for instance, he instructed the prior of Colmar to punish two of the brethren, Erbonus and Humbertus, who illicitly entered the convent of St. Agnes in Strasbourg, probably in order to administer confession to the nuns during the interdict. He also scolded the local abbess for accepting or perhaps even inviting the friars in the first place and then expressed his dismay at a similar incident involving the local Franciscans, who avoided the

et volumus quod non possint eligi vel assumi ad officium prioratus vel supprioratus aut diffinicionis seu visitacionis."

${ }^{34}$ Ibid., 1:307-9.

${ }^{35}$ Ibid., 2:135: “. . . priorem provincialem verberaverunt, ad terram prostraverunt, ceperunt et violenter in carcerali custodia detinuerunt; ac interficere voluerunt et socium eius et famulum vulneraverunt."

${ }^{36}$ Ibid., 2:281-82: "quia propter indiscriminacionem ipsius in regimine multe turbaciones et disceptaciones in spiritualibus et temporalibus in dicto conventu contigerunt et graviores futuras verisimiliter formidamus."

${ }^{37}$ Ibid.

${ }^{38}$ Ungedruckte Dominikanerbriefe des 13. Jahrhunderts, ed. Heinrich Finke (Paderborn, 1891). And see Sandrine Turck, Les dominicaines à Strasbourg, entre prêche, prière et mendicité (1224-1420), Publications de la Société savante d'Alsace et des regions de l'Est, Collection Recherches et Documents, 68 (Strasbourg, 2002), pp. 39-45; Andreas Rüther, Bettelorden in Stadt und Land: Die Straßburger Mendikantenkonvente und das Elsaß im Spätmittelalter, Berliner historische Studien 26, Ordenstudien 11 (Berlin, 1997). 
magistrates' wrath, and the Dominican nuns, who remained in situ. Later that year the provincial dispatched a friar to one of the local convents for an unstated offense, ordering the prior to incarcerate him perpetually or expel him from the order unless the culprit was able to secure himself a place in a different order outside the province. ${ }^{39}$ All told, Hermann's extant letters mention a dozen major events over a period of four years. ${ }^{40}$

The provincial prior's extant correspondence sheds light on isolated incidents only. Moreover, in this particular period the province's Dominicans had to adjust to the peculiarities of carrying on with their mission while the brethren were mostly exiled and the nuns remaining in the city were besieged by locals, some of whom, ironically, sought entrance to the convent in order to participate in the liturgy. A relatively broader picture emerges from the examination of the provincial chapters' acta over a longer period. It is these documents, by far the wealthiest single source on early Dominican discipline, to which I now turn.

Unlike the well-kept protocols of the order's general chapters, the extant records of provincial assemblies from the early thirteenth to the end of the fourteenth century are incomplete. Despite the best efforts of Dominican historians, many of these texts have been lost for centuries, others may yet be unearthed, and not all of those that have been identified are easy to access. ${ }^{41}$ Among the known acta, moreover, many are fragmentary or otherwise do not (or no longer) contain penitential clauses. Still, nearly full protocols remain from the Italian and Aragonese provinces, and along with other partial records from northern and central Europe they afford a fuller view of the brethren's major infractions.

Documents issued by Dominican provincial administrations, augmented by the occasional records discussed above, report over one hundred major incidents between 1250 and 1400 . Jointly these incidents involved hundreds of friars convicted of rebellion, violence, forgery, desertion, rioting, wrongful imprisonment, heresy, apostasy, debt, gross mismanagement, and sexual depravity. ${ }^{42}$ In thirty-four cases the punish-

${ }^{39}$ Ungedruckte Dominikanerbriefe, ed. Finke, 110, 112, and 140, pp. 132-33 and 153.

${ }^{40}$ Ibid., 93, 96, 109, 113-14, 124, and 141, pp. 116, 119, 131-32, 134-35, 143, and 154-55.

${ }^{41}$ Masetti, Monumenta (above, n. 18), 1:29.

${ }^{42}$ None of the following incidents overlaps with those previously mentioned: Fritz Bünger, "Ein Dominikaner-Provinzialkapitel in Luckau (1400)," Zeitschrift für Kirchengeschichte 34 (1913), 85 and 86; Heinrich Finke, "Zur Geschichte der deutschen Dominikaner im XIII. und XIV. Jahrhundert," Römische Quartalschrift für christliche Altertumskunde und für Kirchengeschichte 8 (1894), 383; Thomas Kaeppeli, “Acta capitulorum provinciae Lombardiae (1254-93) et Lombardiae inferioris (1309_ 1312)," Archivum Fratrum Praedicatorum 11 (1941), 156; Acta capitulorum provincialium provinciae Romanae (1243-1344), ed. Thomas Kaeppeli and Antoine Dondaine, Monumenta Ordinis Fratrum Praedicatorum Historica 20 (Rome, 1941), pp. 14, 39, 124, 140-41, 142, 167, 171, 175, 197, 200, and 228-29; Benedikt Maria Reichert, "Akten der Provinzialkapitel der Dominikanerordensprovinz Teutonia, 1398, 1400, 1401, 1402," Römische Quartalschrift für christliche Altertumskunde und für Kirchengeschichte 11 (1897), 300 and 311; Thomas Kaeppeli, "Ein Fragment der Akten des in Friesach 1315 gefeierten Kapitels der Provinz Teutonia,” Archivum Fratrum Praedicatorum 48 (1978), 73; and Acta, ed. Douais, 1:100, 147, 203, 280, 290, and 427. This is not a complete list of published acta of provincial chapters in the examined period but only of those that document major violations, as discussed above. A unique unpublished source is Zaragoza, Biblioteca Universitaria, MS 185 (previously 97), which contains a sixteenth-century transcription of the Aragonese Dominicans' provincial chapters between 1250 and 1530. Major infractions are recorded on pp. 107-8 (1321), 233 (1352), 247-48 (1353), 288-90 (1357), 304 (1358), 376-77 (1369), 397 (1371), 448 (1377), and 590 (1395). 
ment remains obscure or is delegated to a local prior or convent. Yet in thirty-five cases the offenders were ordered to be relocated to another convent; in twenty-seven cases they were incarcerated, sometimes for life; and eleven cases were resolved by expelling the offenders from the order. ${ }^{43}$ The many hundreds of friars convicted of minor disobediences (not covered by the present survey) suffered lighter punishments, usually a combination of fasts, flogging, and prayers.

There are limitations to using the provincial and general acta, of course. Their laconic nature frustrates any hope for understanding the circumstances of individual events and pushes attempts to reconstruct motivations for violations beyond the realm of responsible speculation. Moreover, given the haphazard survival of relevant records, the offenses' apparent distribution across time is often misleading. For instance, the seven cases documented for the decade 1271-80 involved at least triple that number of offenders, and at least thirty friars were complicit in the seven cases reported for 1301-10. Arguing meaningfully for any distribution across space is equally problematic since a single occasion-for instance, a rebellion among the German brethren in 1301—could involve numerous men spread among different convents.

As a rule, however, where the extant documentation is better, the number of infractions is higher. Thus, toward the end of the fourteenth century, the internal reform spearheaded by Raymond of Capua, which mainly focused on Italy and Germany, generated more reports of infractions. But whether a similarly powerful magnifying glass placed over any other region, at any other period, would have exposed a similar picture is currently impossible to know. In sum, beyond attesting the ubiquity of major violations, the available records do not allow us to generalize about particular periods or regions, for instance, regarding the influence of the order's recruitment practices after the onset of the plague cycle in 1347-48, differences in landowning patterns among various cities, and a region's degree of urbanization.

The composite image emerging from the Dominican records can be augmented. Even if we confine ourselves to major infractions and grave punishments when examining other types of sources, the number of documented violations will increase. Mendicant, let alone monastic, chroniclers routinely mention friars involved in activities that were dubious, unorthodox, criminal, and even traitorous; ${ }^{44}$ and

\footnotetext{
${ }^{43}$ Prisons became required facilities in every Dominican convent (or province) at least from 1238. See Acta, ed. Reichert, 1:10. Detailed instructions on how to construct and run a prison were promulgated by the Ferrara provincial chapter in 1279. See Kaeppeli, "Acta capitulorum provinciae Lombardiae," p. 156. In 1277 Ieronimo of Ascoli, the Franciscan minister general, similarly instructed "quod carceres fortes et multiplices habeantur" throughout the order's provinces, according to Nicolas Glassberger, Chronica, Analecta Franciscana 2 (Quaracchi, 1887), p. 89. The Franciscan general chapter meeting in Padua that year promulgated a similar resolution. See A. G. Little, ed., "Decrees of the General Chapters of the Franciscan Order, 1260-1282,” English Historical Review 13 (1898), 703-8, at p. 707.

${ }^{44}$ Anonymous, Annales Colmarienses maiores, ed. Philipp Jaffé, MGH SS 17 (Hannover, 1861), pp. 203, 222, and 224; Thomas of Eccleston, The Coming of the Friars Minor to England, trans. Placid Hermann (Chicago, 1961), pp. 98-99 and 111; Salimbene de Adam, Cronica 111, 117, 473, and 932, ed. Giuseppe Scalia, CCCM 125 and 125A (Turnhout, 1998-99), 1:113-14, 120, 494, and 2:960; Anonymous, Chronica XXIV generalium Ordinis Minorum, Analecta Franciscana 3 (Quaracchi, 1897), pp. 87-88 and 469; La cronaca di S. Domenico di Perugia, ed. Andrea Maiarelli, Quaderni del Centro per il Collegamento degli Studi Medievali e Umanistici nell’Umbria 36 (Spoleto, 1995), 59, pp. 50-51.
} 
comparable instances can be gleaned or inferred from urban statutes, sermons, papal dispensations, and canonization processes, although that has not been attempted here.

There are also other, less accessible documents of practice that throw further light on the matter, such as unpublished court records. Since the mendicants were theoretically autonomous or else answered directly to the pope, their prosecution by local bishops or secular magistrates was sporadic at best. Yet such cases do occasionally emerge: in 1326 Bartolo, a Bolognese Franciscan, was fined five hundred lire and later incarcerated at the municipal prison for admitting a boy into the order against his parents' wish (the incident was later followed by a rescue attempt and a brawl);45 Thomas, the subprior of the Dominican convent in Pisa, was convicted in 1362 of harboring a relative at the cloister while the latter was being pursued as a criminal; 46 and in 1369 the Pisan Dominicans Jacopo dela Seta and Jacopo di Petri were defrocked and clapped into prison in the order's convent in Lucca, allegedly for siding with the emperor. ${ }^{47}$

Other kinds of archival sources can be revealing, too. In her testament, Jacobella, a Venetian matron, bequeathed six ducats to an Augustinian friar named Benedetto, who had been incarcerated for an unspecified offense. ${ }^{48}$ The money could have been useful to purchase his pardon or simply alleviate his conditions, despite the fact that incarceration in Venice was- untypically for that period-free. ${ }^{49}$ Another Augustinian friar, likewise incarcerated indefinitely in Venice, made his documentary debut several years later, when his escape (along with that of a local nobleman) prompted the Venetian magistrates to organize a search party. ${ }^{50}$ However sporadically they resurface, such incidents move us closer to a broader and better-grounded reconstruction of medieval mendicants' social history. And as Donald Logan's magisterial study of religious apostasy in England suggests, combing local archives is bound to improve our picture of mendicant deviance even further. ${ }^{51}$

\footnotetext{
${ }^{45}$ Archivio di Stato di Bologna, Governo, Riformagioni e Provvigioni 200, fols. 312v-313r (21 February 1326). For similarly antagonizing recruitment practices among the London friars see A. H. Thomas, ed., Calendar of Select Pleas and Memoranda of the City of London, 4 (Cambridge, Eng., 1932), p. 182 (13 July 1392). The trope of parents being appalled by their child's taking a friar's habit is common in mendicant hagiography. See Gerardus de Fracheto, Vitae fratrum Ordinis Praedicatorum, ed. Benedikt Maria Reichert, Monumenta Ordinis Fratrum Praedicatorum Historica 1 (Rome, 1896), 3.14 (pp. 110-11), 4.13 .7 (p. 186), 4.17 .3 (p. 201), 4.22 .3 (p. 211); and Thomas of Eccleston, The Coming of the Friars Minor, trans. Herman, p. 114.

${ }^{46}$ Archivio Arcivescovile di Pisa, Atti Straordinari 8, fol. 80r-v (14 February 1362).

${ }^{47}$ Archivio Arcivescovile di Lucca, Tribunale Criminale 24, fol. 24r-v (11 April 1369).

${ }^{48}$ Archivio di Stato di Venezia, Cancellaria Inferiore, Miscellanea Testamenti, Notai Diversi B.22, no. 782 (13 October 1388).

${ }^{49}$ See G. Geltner, The Medieval Prison: A Social History (Princeton, N.J., 2008), pp. 12-17.

${ }^{50}$ Archivio di Stato di Venezia, Consiglio di Dieci, Deliberazioni (Miste) 8, fol. 13r (10 September 1393).

${ }^{51}$ F. Donald Logan, Runaway Religious in Medieval England, c. 1240-1540, Cambridge Studies in Medieval Life and Thought, 4th ser., 32 (Cambridge, Eng., 1996), pp. 241-50. Several cases of apostasy among mendicants in the diocese of Lucca are reported in Archivio Arcivescovile di Lucca, Tribunale Criminale 33 bis, fols. 89r-90v (8 November 1382); 37, fols. 103v-104v (23 November 1386), and fol. 128v (1 September 1387). The murder of a London Carmelite by a fellow friar is attested in Kew, National Archives, JUST1/369/M22-OCarm. (1297).
} 
More work certainly lies ahead, yet it is already fair to say that, given the evidence presented so far, there is no reason not to take satirists and polemicists at their word or to dismiss the self-criticism of mendicant reformers as a rhetoric of fallenness. Official deviance among friars was substantial according to both their own administrative accounts and an array of external sources and regardless of how favorably it might have compared with misconduct by their lay or clerical contemporaries. ${ }^{52}$ But what role, if any, did such behavior play in the development of resentment against friars? To begin answering that key question, I now move to examine how contemporary observers learned about and construed the friars' deviance.

\section{Secrets, Scandals, and the Public Sphere}

The Dominican constitutions emphasized the brethren's strict routine and hierarchy and placed a high premium on obedience. Yet, whether owing to their innate human corruption or to integral sociological mechanisms, the brethren overstepped their prescribed normative boundaries, and they did so often. That this should be typical of any society, including a community of religious, was originally put forward by the social philosopher Émile Durkheim (1858-1917): "Imagine a society of saints, a perfect cloister of exemplary individuals. Crimes, properly so called, will there be unknown; but faults which appear venial to the layman will create there the same scandal that the ordinary offense does in ordinary consciousnesses." 53

Durkheim sought to demonstrate that crime and deviancy are routine and relative rather than pathological and absolute. Without detracting from his main thesis, which in essence is widely accepted today, it is doubtful whether what could count for deviancy in a community of saints would appear merely "venial to the layman." After all, laymen identified groups such as monks as morally superior, and it is quite possible that, however unavoidable, minor violations among them would resonate not only within the perfect community but also, and perhaps especially loudly, outside it once they became known.

Either way, by focusing on major violations and reprimands, the previous section sought to adjust the parameters from angelic to human ones: violence, fraud, sexual promiscuity, desertion, and rebellion would have struck contemporaries as serious offenses, to judge by secular jurisprudence and penal practices. ${ }^{54}$ But whatever the scale-monastic or civic, religious or secular-Dominican administrators were

\footnotetext{
${ }^{52}$ On late-medieval crime rates, a subject riddled with documentary and interpretative problems, see Claude Gauvard, Violence et ordre public au moyen âge, Les Médiévistes Français 5 (Paris, 2005); Anthony Musson, ed., Boundaries of the Law: Geography, Gender and Jurisdiction in Medieval and Early Modern Europe (Aldershot, Eng., 2005); Karen Jones, Gender and Petty Crime in Late Medieval England: The Local Courts in Kent, 1460-1560, Gender in the Middle Ages 2 (London, 2006); Valérie Toureille, Vol et brigandage au moyen âge (Paris, 2006); Trevor Dean, Crime and Justice in Late Medieval Italy (Cambridge, Eng., 2007); and G. Geltner, "I registri criminali dell'Archivio Arcivescovile di Lucca: Prospettive di ricerca," in Il patrimonio documentario della chiesa di Lucca: Prospettive di ricerca, ed. Sergio Pagano and Pierantonio Piatti (Florence, 2010 [forthcoming]).

${ }^{53}$ Émile Durkheim, The Rules of Sociological Method, trans. Sarah A. Solovay and John H. Mueller, 8th ed. ([New York], 1962), pp. 68-69.

${ }^{54}$ See Bernard Schnapper, Les peines arbitraires du XIIIe au XVIIIe siècle: Doctrines savantes et usages français (Paris, 1974); Marco Cattini and Marzio A. Romani, eds., Il potere di giudicare: Giusti-
} 
eager to keep allegations, confrontations, and violations confined to the order's concentric circles: convent, province, order. ${ }^{55}$ What happened within them was no stranger's business; indeed, it was a secretum. And the purpose of defending such secreta, as repeatedly stated in the chapters' proceedings, was to avoid scandal. ${ }^{56}$

It is no accident that the term scandalum in Dominican as well as other mendicant documents is closely linked to the brethren's relations with the outside world and the disclosure of the orders' "secrets." 57 Already in 1239, the general chapter gathered at Paris admonished "lest our brethren go to the houses of secular men or clerics on funeral processions or receive [anything] to provoke evident scandal." 58 And henceforth the term appears frequently in similar contexts: in 1242 the chapter meeting at Bologna warned the priors "lest they allow fugitives or apostates to join other orders or let them wander elsewhere, causing a scandal to our order"; 59 a decade later, the brethren were instructed to avoid supplying "prelates or clerics anywhere with grounds for disturbance or scandal, but rather hold them in reverence and respect"; 60 and the 1268 chapter assembled at Viterbo insisted that the friars should avoid "issues . . . and grounds from which a scandal might arise." 61

Nor was the term's use in such contexts unique to the Friars Preachers: in 1335, for instance, an Augustinian provincial chapter condemned recent clothing practices among the brethren as strange, effeminate, and leading to "a scandal in the eyes of secular men (scandalum in oculis secularium)"; ${ }^{62}$ and in 1362 the Carmelite

zia, pena, e controllo sociale negli stati d'Antico regime, Cheiron 1 (Brescia, 1983); Nicole Gonthier, La châtiment du crime au moyen âge, XIIe-XVIe siècles (Rennes, 1998); and above, n. 52.

${ }^{55}$ Acta, ed. Reichert, 1:5 (Paris, 1234); Acta, ed. Douais 1:119 (Limoges, 1266).

${ }^{56}$ Acta, ed. Kaeppeli and Dondaine (above, n. 42), p. 228 (Castello, 1323); G. Stephens, "Brottstycken av en Dominikaner-Ordens eller Predikare-Brödernas Statut- eller Capitel-Bok infrån XIII. Århundradet, och gällande för 'Provincia Dacia' eller de Nordiska Riken," Kirkehistoriske Samlinger 1 (1849-52), 545-642; 2 (1853-56), 128-29; Berthold Altaner, “Aus den Akten des Rottweiler Provinzialkapitels der Dominikaner vom Jahre 1396," Zeitschrift für Kirchengeschichte 48 (1929), 8-9. Jacques Guy Bougerol, Les manuscrits franciscains de la Bibliothèque de Troyes, Spicilegium Bonaventurianum 23 (Grottaferrata, 1982), pp. 12-13 (K.55, V.879), mentions a collection of quaestiones dealing specifically with friars' scandala. And see, to the same effect, the exemplum related by Thomas of Eccleston, The Coming of the Friars Minor, trans. Herman, pp. 173-74.

${ }^{57} \mathrm{On}$ the essentially public nature of scandal in the Middle Ages see Lindsay Bryan, "'Scandle is heaued sunne,"” Florilegium 14 (1995-96), 71-86; and eadem, "Periculum animarum: Bishops, Gender, and Scandal," Florilegium 19 (2002), 49-73.

${ }^{58}$ Acta, ed. Reichert, 1:11: "ne fratres nostri vadant ad domos secularium vel clericorum pro funeribus, nec recipiant cum scandalo evidenti." Repeated verbatim in the acts of the Bologna chapter of 1240 (ibid., 1:15).

${ }^{59}$ Ibid., 1:24: "Monemus priores ne in scandalum ordinis nostri fugitivos et apostatas nostros in aliis religionibus stare vel alias vagari permittant.” Repeated verbatim ibid., 1:29 (Bologna, 1244).

${ }^{60}$ Ibid., 1:63 (Bologna, 1252): "Caveant fratres ubique ne prelatis vel clericis dent materiam turbacionis vel scandali, sed pocius eos habeant in reverencia et honore." A similar injunction appears in the proceedings of the Franciscan general chapter at Lyons in 1274. See Ehrle, "Die ältesten Redactionen" (above, n. 22), p. 43.

${ }^{61}$ Acta, ed. Reichert, 1:143: "questiones . . . et causas de quibus potest oriri scandalum."

62 "Definitiones antiquorum capitulorum provinciae Franciae, O. N.," Analecta Augustiniana 4 (1911-12), 163. And see letters 1 and 2 of William of Cremona, "Litterae Prioris Generalis Fr. Guillelmi de Cremona," ibid., pp. 29-32 and 57-65; and letter 7 of Gregory of Rimini, "Litterae Prioris Generalis Ordinis Fr. Gregorii Ariminensis,” ibid., 5 (1913-14), 7. 
general chapter prescribed incarceration or expulsion for anyone provoking public brawls, noting that they cause "a scandal in the presence of secular men (scandalum coram secularibus)." 63 It is in this behavioral and semantic range, converging on the urban public sphere, that the penitential clauses surveyed above dubbed a brother's deviance as "scandalous." 64 Disobedience was indeed sinful, but public exposure itself caused serious damage, for it rendered obsolete the available "systems of evasion," or a community's capacity to ignore trespasses that otherwise would have remained-at worst-open secrets. ${ }^{65}$

But what to do when the infractions themselves are perpetrated in public, as can be inferred from some of the offenses cited in the previous section? To recall, fra Marino of Urbino was prosecuted for "a crime committed by him in the city of Camerino"; Ugolino of Pesaro's prior was instructed to investigate "intolerable excesses ... especially concerning what he [Ugolino] did on a public way"; 66 the two Baltic priors were ejected for "scandals perpetrated by them and by their brethren in the city of Greifswald"; 67 and the records regarding both Bartolo, the Bolognese Franciscan, and Thomas, the Pisan Dominican, likewise situate their offenses in the open view. ${ }^{68}$

There is no shortage of similarly visible incidents: in 1352 three Dominicans left their convent at Panyana without permission and were later discovered consuming chicken and wine in public, provoking a "scandalum et opprobrium manifestum. ${ }^{69}$ In 1372 a group of armed friars stormed the cathedral at Arles after being denied the right to preach there. They interrupted the service and publicly insulted the vicar general and the members of the local chapter. ${ }^{70}$ And in 1370 the Dominican nuns of St. Marx, St. Nikolaus in Undis, and St. Katharina in Strasbourg abandoned their convents and were promptly excommunicated. In response, and perhaps revealing some of the motivations for their departure, the sisters brought forward allegations of material corruption and sexual depravity among their

\footnotetext{
${ }^{63}$ Acta capitulorum generalium Ordinis B. V. Mariae de Monte Carmelo, ed. Gabriel Wessels, 1 (Rome, 1912), p. 50, and see pp. 58 and 119. For some major infractions among Carmelites see Atti dei capitoli provinciali di Toscana dei carmelitani, 1375-1491, ed. Andrea Sabatini, Archivum Historicum Carmelitanum 4 (Rome, 1975), pp. 23, 32, 35, 36, and 61.

${ }^{64}$ The church's omnipresence and claims to authority, on the one hand, and the myriad critiques launched against its members' shortcoming, on the other, rendered it a fulcrum of the premodern public sphere-a participatory discourse more aptly described for that period by Mikhail Bakhtin, Rabelais and His World, trans. Hélène Iswolsky (Cambridge, Eng., 1968), than by Jürgen Habermas, The Structural Transformation of the Public Sphere: An Inquiry into a Category of Bourgeois Society, trans. Thomas Burger with Frederick Lawrence (Cambridge, Mass., 1989). Eschewing Habermas's chronology, but not his (and others') analytical framework, is Carol Symes, "Out in the Open, in Arras: Sightlines, Soundscapes, and the Shaping of a Medieval Public Sphere," in Cities, Texts and Social Networks, 400-1500: Experiences and Perceptions of Medieval Urban Space, ed. Caroline Goodson, Anne E. Lester, and Carol Symes (Aldershot, Eng., 2010 [forthcoming]).

${ }^{65}$ On "systems of evasion" see Bronislaw Malinowski, Crime and Custom in Savage Society (London, 1926), pp. 80-84.

${ }^{66}$ Registrum (above, n. 26), "Provincia Lombardiae inferioris" 32, p. 10 (emphases mine).

${ }^{67}$ Acta, ed. Reichert, 1:139-40 (emphasis mine).

${ }^{68}$ See above, nn. 45-46.

${ }^{69}$ Zaragoza, Biblioteca Universitaria, MS 185 (previously 97), pp. 247-48.

${ }^{70}$ Louis Stouff, "Le couvent des prêcheurs d'Arles, XIIIe-XVe siècle," in L'Ordre des Prêcheurs et son histoire en France méridionale, Cahiers de Fanjeaux 36 (Toulouse, 2001), pp. 71-72.
} 
male counterparts. True, false, or exaggerated, the charges were taken at face value and amplified by local clergymen and civic leaders in order to advance their converging agendas, namely, limiting the Dominicans' access to urban property. ${ }^{71}$ The incident also highlights another major and often knowable aspect of mendicant misbehavior, namely, a friar's (or in this case, a sister's) abandonment of a convent, an act technically referred to as apostasy. A thorough survey of such cases among members of English religious houses lists no fewer than ninety-four cases among the four major mendicant orders prior to $1400 .{ }^{72}$ In some instances, wayward brethren were accused of further offenses such as theft, heresy, and illicit marriage.

General awareness of the friars' misbehavior was understandably a serious concern, especially given their exposure to the world, for, unlike monks, mendicants congregated mostly in urban centers. And since some of their staple missionspreaching, holding masses, and conducting burials-were highly public affairs, it became all the more difficult to avoid open scrutiny. ${ }^{73}$ Moreover, with the friars' proliferation, their ubiquitous convents became accessible to city dwellers and visitors alike. ${ }^{74}$ Their intentional location, at least initially, near the physical edges of cities, among lepers, vagabonds, and prostitutes, created a proximity that sometimes threatened their reputation. Toward the end of the thirteenth century, for example, the Sienese Servites urged the commune to enforce a "prostitute-free zone" around their convent precisely on such grounds. ${ }^{75}$ And it was with similar concerns in mind that the Bolognese Dominicans helped prosecute the proprietors of an adjacent brothel in $1360 .{ }^{76}$ But the brethren's real Achilles' heel was their

\footnotetext{
${ }^{71}$ Michael Tönsing, Johannes Malkaw aus Preussen (ca. 1360-1416): Ein Kleriker im Spannungsfeld von Kanzel, Ketzerprozess und Kirchenspaltung, Studien zu den Luxemburgern und ihrer Zeit 10 (Warendorf, 2004), pp. 142-43; Rüther, Bettelorden in Stadt und Land (above, n. 38).

${ }^{72}$ Logan, Runaway Religious (above, n. 51), pp. 241-50. For a taxonomy of apostasy in the Middle Ages see ibid., pp. 9-41.

${ }^{73}$ Jacques Le Goff et al., "Ordres mendiants et urbanisation dans la France médiévale," Annales: Économies, sociétés, civilisations 25 (1970), 924-87; L. Pellegrini, "L'ordine francescano e la società cittadina in epoca bonaventuriana: Un'analisi del 'Determinationes quaestionum super Regulam Fratrum Minorum,'” Laurentianum 15 (1974), 154-200.

${ }^{74}$ Richard W. Emery, The Friars in Medieval France: A Catalogue of French Mendicant Convents, 12001550 (New York, 1962), pp. 1-17; John R. H. Moorman, Medieval Franciscan Houses, Franciscan Institute Publications, History Series, 4 (St. Bonaventure, N.Y., 1983), p. ix; John B. Freed, The Friars and German Society in the Thirteenth Century, Medieval Academy of America Publication 86 (Cambridge, Mass., 1977), pp. 22-23; Aubrey Gwynn and R. Neville Hadcock, Medieval Religious Houses: Ireland (London, 1970), pp. 208-305 and 307-26; David Knowles and R. Neville Hadcock, Medieval Religious Houses: England and Wales, new ed. (London, 1971), p. 92 (table H); Ian B. Cowan and David E. Easson, Medieval Religious Houses: Scotland, 2nd ed. (London, 1976), pp. 114-42 and 152-55.

${ }^{75}$ I Frati Servi di S. Maria, dalle origini all'approvazione (1233 ca.-1304), 2: Documentazione, ed. Franco Andrea Dal Pino, Recueil de Travaux d'Histoire et de Philologie, 4th ser., 50 (Louvain, 1972), 3.225 (p. 359) and 3.288-89 (pp. 416-17).

${ }^{76}$ Archivio di Stato di Bologna, Curia del Podestà, Giudici ad Maleficia, Libri Inquisitionum 191, Reg. 4, fols. 101r-103v. Prostitutes' vicinity occasionally proved too tempting. According to Ruth Mazo Karras, Common Women: Prostitution and Sexuality in Medieval England (New York, 1996), p. 30, a "'monkwhore' or 'friarwhore' could be the mistress of a member of a religious order, although she might also be a prostitute who catered particularly for those groups"; and she asserts that "priests, monks, and friars were certainly among the[ir] clients” (p. 45).
} 
involvement with urban, princely, and royal administrations in various capacities. ${ }^{77}$ The papacy, too, made ample use of their services as preachers, missionaries, inquisitors, jurists, teachers, and theologians and raised many brethren to positions of authority. It is estimated, for instance, that by 1320 there were some 450 ecclesiastical dignitaries from among the Dominicans alone, including two popes and a dozen cardinals. ${ }^{78}$ Such power and prominence proved to be a mixed blessing.

Perhaps more than any other member of the late-medieval church, then, friars were conspicuous. As such it was incumbent upon them to avoid the wrath of one group or the other in a highly factional environment. But with so many fingers in so many pies, maintaining neutrality was a nearly impossible feat. Moreover, convents tended to attract residents of the local city or its hinterland, a situation that rendered impractical the orders' injunctions against favoring or aiding a particular party. ${ }^{79}$ Furthermore, when internal urban strife temporarily waned, friars were often accused of collaborating with external enemies: the emperor, the pope, a hostile foreign ruler; ${ }^{80}$ or vice versa: an invading power would target them for siding with the local population. ${ }^{81}$

Fame and power, in fine, had their costs above and beyond the tough challenges of the mendicant regime, and their threat or abuse often led the friars' antagonists to defame them as hypocritical and corrupt. As the Franciscan chronicler Salimbene put it, "Wisdom is extremely necessary for men in religious orders because they have many assailants, detractors, enemies, and persecutors, who gladly put a blot

\footnotetext{
${ }^{77}$ Notably, but not exclusively, with Louis IX of France (St. Louis). See Lester K. Little, "Saint Louis' Involvement with the Friars," Church History 2 (1964), 125-43; William Chester Jordan, St. Louis and the Challenge of the Crusade: A Study in Rulership (Princeton, N.J., 1979), pp. 135-213; Xavier de La Salle, Le service des âmes à la cour: Confesseurs et aumôniers des rois de France du XIIIe au XVe siècle, Mémoires et Documents de l'École des chartes 43 (Paris, 1995), pp. 99-109, 261-83, 31015, and 318-22. See, more broadly, C. H. Lawrence, The Friars: The Impact of the Early Mendicant Movement on Western Society (London, 1994), pp. 166-201.

${ }^{78}$ R. F. Bennett, The Early Dominicans: Studies in Thirteenth-Century Dominican History (Cambridge, Eng., 1937), pp. 128-44.

${ }^{79}$ Bernard Gui, De fundatione et prioribus conventuum provinciarum Tolosanae et provinciae Ordinis Praedicatorum, ed. P. A. Amargier, Monumenta Ordinis Fratrum Praedicatorum Historica 24 (Rome, 1961); "Cronaca del convento di Santa Caterina dell'Ordine dei Predicatori in Pisa," Archivio storico italiano, 1st ser., 6/2 (1845), 397-593. And see Daniel R. Lesnick, Preaching in Medieval Florence: The Social World of Franciscan and Dominican Spirituality (Athens, Ga., 1989), pp. 47, 72-73, and 86-92; Carol Lansing, Power and Purity: Cathar Heresy in Medieval Italy (New York, 1998), pp. 137-39; Turck, Les dominicaines à Strasbourg (above, n. 38), pp. 159-69; and George W. Dameron, Florence and Its Church in the Age of Dante (Philadelphia, 2005), pp. 104-5. On the orders' unrealistic injunctions against involvement in local politics see Acta, ed. Douais, 1:32 (Marseilles, 1248); and "Antiquiores quae extant definitiones capitulorum generalium ordinis," Analecta Augustiniana 4 (1911-12), 235-36 (Milan, 1343).

${ }^{80}$ Josef Wiesehoff, Die Stellung der Bettelorden in den deutschen freien Reichstädten im Mittelalter (Leipzig, 1905); Anne Müller, "Conflicting Loyalties: The Irish Franciscans and the English Crown in the High Middle Ages," Proceedings of the Royal Irish Academy 107 (2007), 87-106; Grieco, "Franciscan Inquisition" (above, n. 14).

${ }^{81}$ Chronicon de Lanercost, M.CC.I.-M.CCC.XLVI., ed. Joseph Stevenson, Bannatyne Club Publications 65 (Edinburgh, 1839), pp. 254, 260-61, 265, 275, and 282; Chronica, ed. Reichert (above, n. 14), pp. 22 and 24; Die Chronik Johanns von Winterthur, ed. Friedrich Bathgen with C. Brun, MGH SS rer. Germ. N. S. 3 (Berlin, 1924), pp. 197-98, 239-40, and 268-69.
} 
on the elect [Ecclesiasticus 11.33]." 82 Evidently, it was the kind of wisdom not all friars shared. No matter how eager Salimbene was to underscore his brethren's victimization, he could never ignore their own contributing role to this state of affairs. Thus, charting misbehavior among mendicants lays an important, albeit not exclusive, foundation for understanding the friars' disrepute.

${ }^{82}$ Salimbene, Cronica (above, n. 44), 177, 1:183: "Est autem valde necessaria sapientia viris religiosis, quoniam multos habent mordaces et detractores et inimicos et persecutores, qui libenter ponunt maculam in electis."

G. Geltner is Professor of Medieval History at the University of Amsterdam, Spuistraat 134, 1012 VB Amsterdam, The Netherlands (e-mail: g.geltner@uva.nl). 